\title{
Sensitivity Analysis and Optimization for Selected Supply Chain Management Issues in the Company - Using System Dynamics and Vensim
}

\author{
Elżbieta Kasperska*, Elwira Mateja-Losa**, \\ Rafat Marjasz***
}

\begin{abstract}
The aim of our paper is to present the new results of research work on optimization and simulation for some logistic problems in the company. The System Dynamics (SD) method and the Vensim simulation language are applied in order to solve specific managerial problems described by Forrester in the model of supply chain. The historical model of Customer-Producer-Employment System by Forrester (Forrester, 1961) has not been examined with the sensitivity analysis, from the "automatic" testing perspective. Optimization experiments have not been conducted, either. It is surprising, since the model is old and widely known. The opportunities offered by the Vensim language allow us to perform such analysis. The visualization called "confidence bounds" is used, to show the behaviour of chosen variables over a period of time. The Monte-Carlo method is applied for sampling a set of numbers from within bounded domains (distribution for each searching parameters is specified). The authors of this paper conducted numerous experiments in this scope. This paper presents their results and offers some conclusions formulated at the end.

Keywords: System Dynamics, sensitivity analysis, optimization, Vensim.
\end{abstract}

\section{Introduction and literature review}

The problem of sensitivity analysis and optimization performed on complex, nonlinear, dynamical and multilevels systems is very interesting from the methodological point of view, especially in the area of System Dynamics (SD). System Dynamics (Coyle, 1977, 1994, 1996, 1998, 1999; Forrester, 1961, 1969, 1971, 1972, 1975; Kasperska, 1995, 2002, 2003, 2005; Radosiński, 2001; Sterman, 2002; Wąsik, 1997, 1983) was developed in the late 1950's and early 1960's at the Massachusetts Institute of Technology's Sloan School

\footnotetext{
* Elżbieta Kasperska, dr hab inż., Silesian University of Technology, e.kasperska@polsl.pl, ul. Kaszubska 23, 44-101 Gliwice.

** Elwira Mateja-Losa, dr inż., Silesian University of Technology, e.mateja@polsl.pl, ul. Kaszubska 23, 44-101 Gliwice.

*** Rafał Marjasz, mgr, Silesian University of Technology, r.marjarz@polsl.pl, ul. Kaszubska 23, 44-101 Gliwice.
} 
of Management by Jay W. Forrester. The approach can be applied to dynamics problems arising in complex social, managerial, economic or ecological systems. The main purpose of System Dynamics is to try to discover the "structure" that conditions the observed behaviour of the system over time. System Dynamics tries to pose "dynamic" hypotheses that endogenously describe the observed behaviour of system.

In the area of System Dynamics method, there have not been much theory or practice related to combining simulation and optimization. Although the first trials were sufficiently long ago (Keloharju, 1977, 1980, 1983; Winch, 1976), the fact is that incorporation or embedding simulation to optimization (and vice versa) has not been as popular as it should be in our view. Probably one of the main reasons was the lack of effective tools. Popular software packages originally used in SD modelling and simulation, did not offer possibilities of automatic optimization (for example: languages DYNAMO, DYSMAP (Kasperska and Mateja-Losa, Słota, 2006). Only such packages as COSMIC and COSMOS and Vensim (Ventana, 2007) make it possible to connect simulation and optimization. Hence some papers published in the field of SD (e.g. Coyle, 1996, 1998), though the work on this subject is still scarce. The authors of this paper have some experience with the so-called embedding simulation in optimization and vice versa, having conducted numerous experiments on DYNBALANCE family of models (Kasperska, 2005, 2009; Kasperska and Mateja-Losa, 2005, 2006; Kasperska, Mateja-Losa and Słota, 2000, 2001, 2003, 2006; Kasperska and Słota 2003, 2005, 2006).

The SD models usually contain several parameters. It is interesting to examine the effect of their variation on simulation output. We select some parameters and assign maximum and minimum values along with a random distribution over which to vary them to see their impact on the model behaviour.

Vensim has a method of setting up such sensitivity simulation. Monte Carlo multivariate sensitivity works by sampling a set of numbers from within bounded domains. To perform one multivariate test, the distribution for each specified parameter is sampled, and the resulting values are used in a simulation. When the number of simulations is set, for example, at 200, this process will be repeated 200 times.

In order to perform sensitivity simulation, the user needs to define what kind of probability distribution values for each parameter will be drawn. The simplest distribution is the Random Uniform Distribution, in which any number between the minimum and maximum values is equally likely to occur. The Random Uniform Distribution is suitable for most sensitivity testing and is selected by default. Another commonly-used distribution is the Normal Distribution (or Bell Curve) in which the value near the mean is more likely 
to occur than the values far away from the mean. The results of sensitivity testing can be displayed in different formats. Time graphs display behaviour of a variable over a period of time. The variables spread values which combine to form individual simulation traces.

\section{Research method}

The object of the experiments is the model named "Customer - Production -Employment", described in the literature by Forrester (1961) and Łukaszewicz (1975). The authors of this article used the description of the model, abbreviations for parameters and variables after Łukaszewicz. Our intention is not to present the model, which is well-known, but to draw the reader's attention to the sensitivity and optimization experiments. In our paper we suggest the process of "automatic" sensitivity analysis and optimization by Vensim.

\section{Analysis and study}

Presentation of the object of the experiments and the assumptions of the simulation

Figure 1 presents the structure of the model "Customer - Production - Employment" in Vensim convention. 


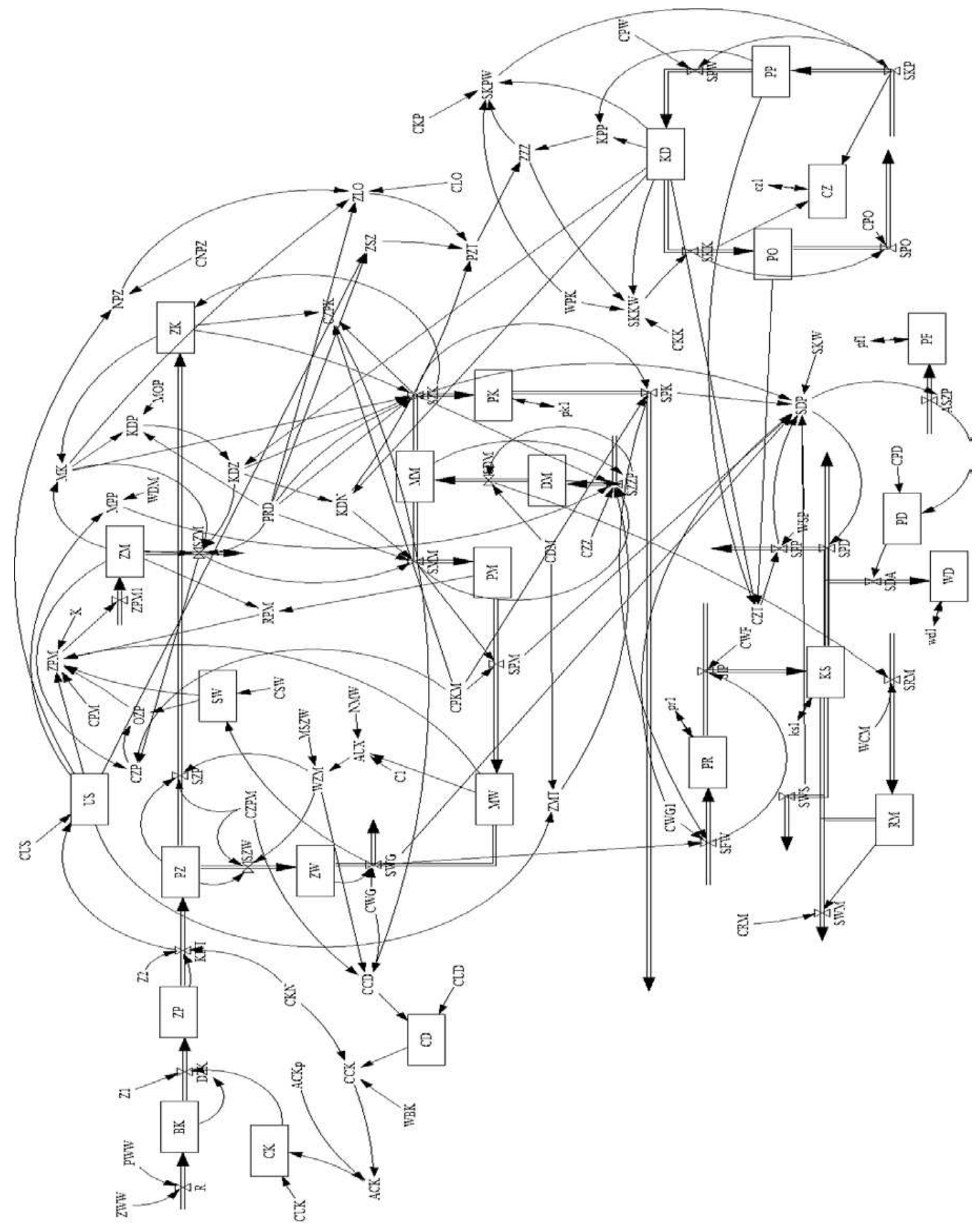

Figure 1. Model "customer-production-employment system" Source: Authors' research, on the basis of Łukaszewicz (1975). 
Table 1 presents the assumptions of the simulation of the above model.

Table 1. Assumptions of the simulation

\begin{tabular}{|c|c|c|c|}
\hline Name of levels & Initial value of level & Name of parameters & $\begin{array}{c}\text { Initial value of } \\
\text { parameter }\end{array}$ \\
\hline \multicolumn{4}{|c|}{ Order Filling, Inventory Reordering } \\
\hline $\mathrm{PZ}$ & 1000 & $\mathrm{~K}$ & 4 \\
\hline $\mathrm{ZW}$ & 700 & CUS & 15 \\
\hline MW & 4000 & CSW & 2 \\
\hline US & 1000 & CWG & 1 \\
\hline \multirow[t]{2}{*}{ SW } & 700 & CZPM & 1 \\
\hline & & CPM & 6 \\
\hline \multicolumn{4}{|c|}{ Manufacturing } \\
\hline ZM & 2800 & PRD & 2.66 \\
\hline ZK & 1200 & CPKM & 6 \\
\hline PM & 4200 & MOP & 1 \\
\hline PK & 1800 & & \\
\hline \multicolumn{4}{|c|}{ Material Ordering } \\
\hline $\mathrm{MM}$ & 6000 & WDM & 6 \\
\hline DM & 3000 & CDM & 3 \\
\hline \multicolumn{4}{|c|}{ Labor } \\
\hline KD & 375 & $\mathrm{CPO}$ & 4 \\
\hline PP & 0 & CKK & 10 \\
\hline PO & 0 & CPW & 3 \\
\hline $\mathrm{CZ}$ & 0 & WPK & 0 \\
\hline CNPZ & 4 & CLO & 20 \\
\hline \multicolumn{4}{|c|}{ Customer Ordering } \\
\hline BK & 30000 & $\mathrm{CKN}$ & 3 \\
\hline ZP & 3000 & CUD & 4 \\
\hline CK & 30 & CZPM & 1 \\
\hline \multirow[t]{2}{*}{$C D$} & 4.7 & CPKM & 6 \\
\hline & & CWG & 1 \\
\hline \multicolumn{4}{|c|}{ Cash, Profit and Dividends } \\
\hline KS & 10000 & WSP & 80 \\
\hline PR & 50000 & CWG1 & 100 \\
\hline RM & 6000 & WCM & 20 \\
\hline PD & 20000 & CRM & 3 \\
\hline $\mathrm{PF}$ & 0 & SKW & 50 \\
\hline
\end{tabular}

Source: based on Forrester (1961) and Łukaszewicz (1975). 
Results of the experiments on sensitivity analysis and optimization for some logistics problems in the company

There are numerous logistics problems in the "Customer - Production -Employment" model. We would like to draw the reader's attention to some of them.

Problem number 1-Too long time of delivery from Producer to Customer. To conduct this experiment we selected the parameters: "CUD" (Time to Adjust Quoted Delivery at Factory), "CZPM" (Delay in Clerical Processing at Factory), "CWG" (Delay in Shipping at Factory), and observed the confidence bounds for variable "CD" (Delay in Quoted Delivery at Factory). The results are presented in Figure 2.

model_klient_producent

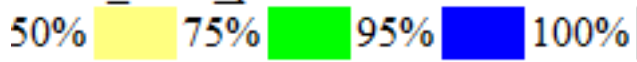

$\mathrm{CD}$

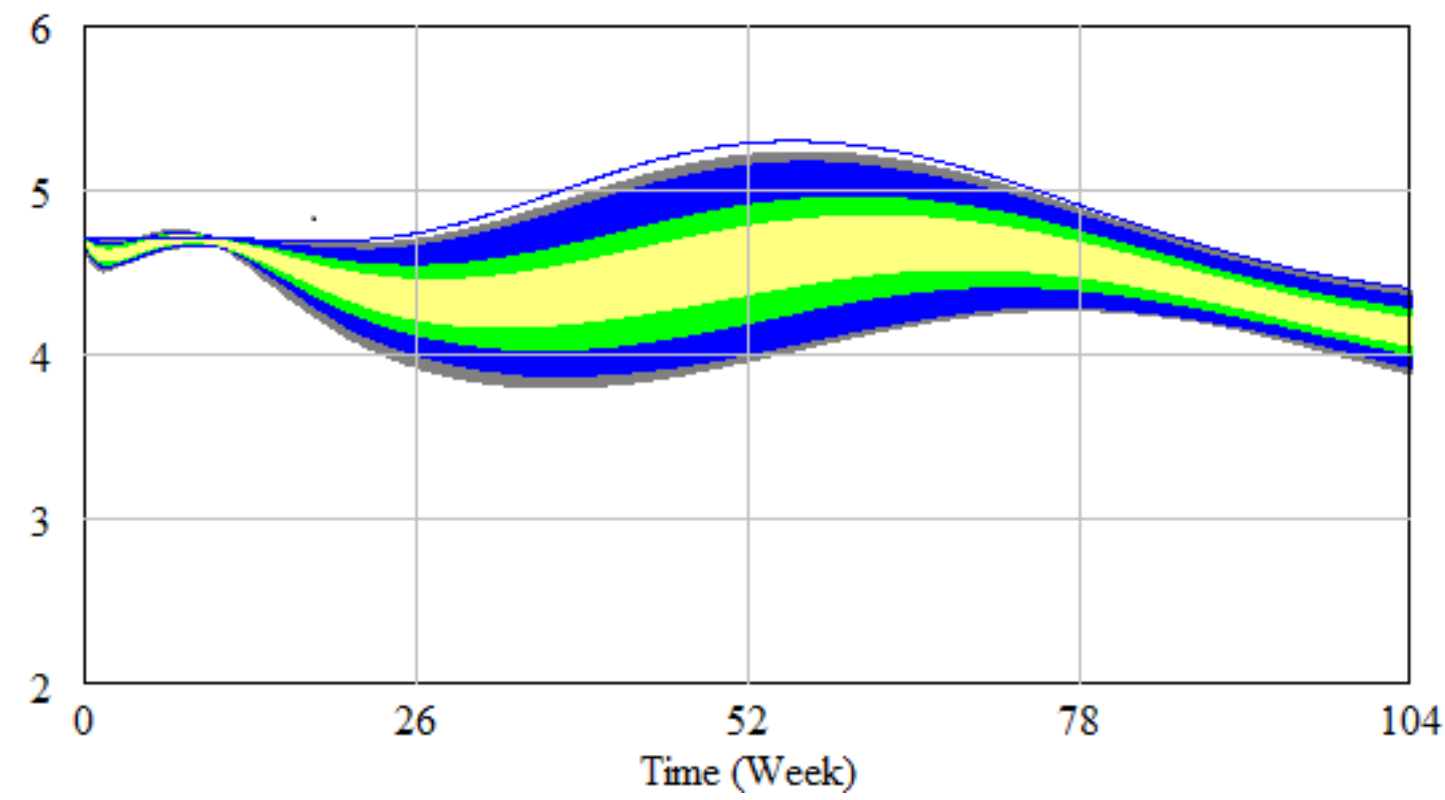

Figure 2. Confidence bounds for variable " $C D$ " for variation of parameters: "CUD" $\epsilon(3,5)$, "CZPM" $\in(0.5,1)$, "CWG" $\in(0.5,1)$

Our aim was to shorten the "CD" time". So we planned the optimization experiment consisting in minimization and used the optimization setup by Vensim, which is shown on windows on Figures 3 and 4. 
Optimization Setup

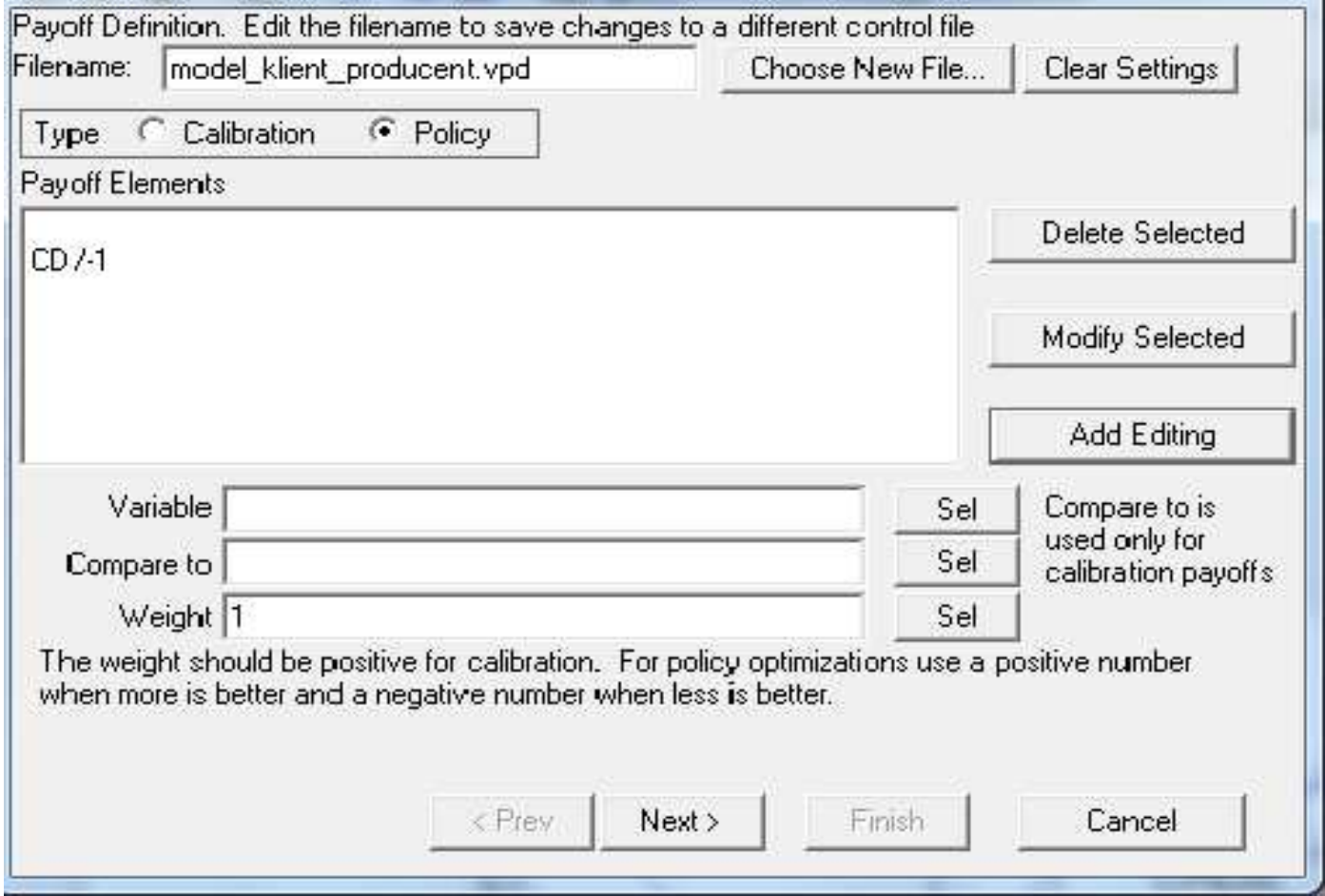

Figure 3. Optimization setup by Vensim

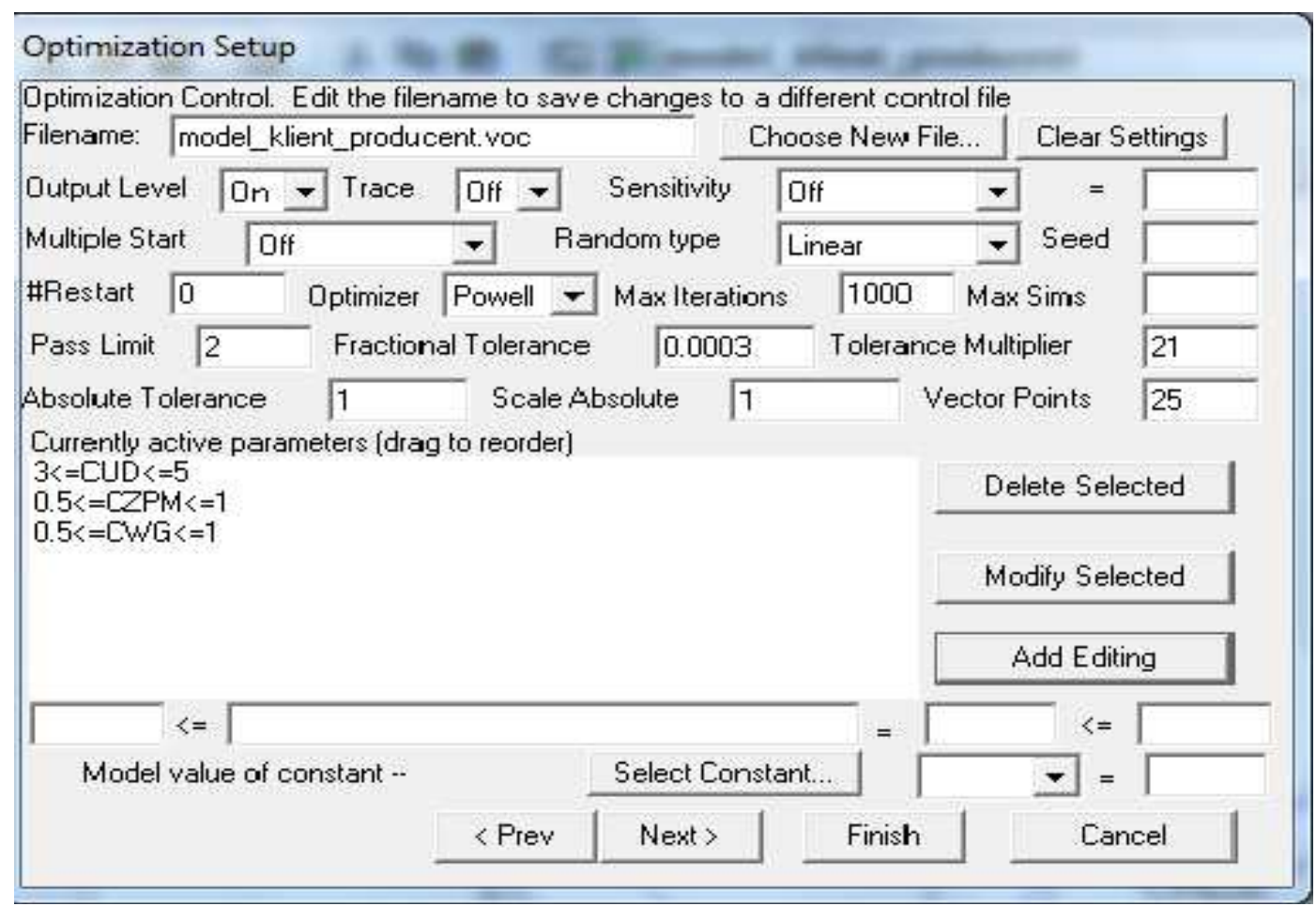

Figure 4. Optimization setup by Vensim 
The results of the experiment are presented in Table 2 .

The second problem is: Too large fluctuations of labour level in the company.

To conduct this experiment we selected the parameter "CLO" (Time for Backlog Adjustment at Factory), and observed the confidence bounds for variables: "KD" (Production Workers at Factory), "CZ" (Total Labour Change at Factory). The results are shown in Figures 5 and 6.

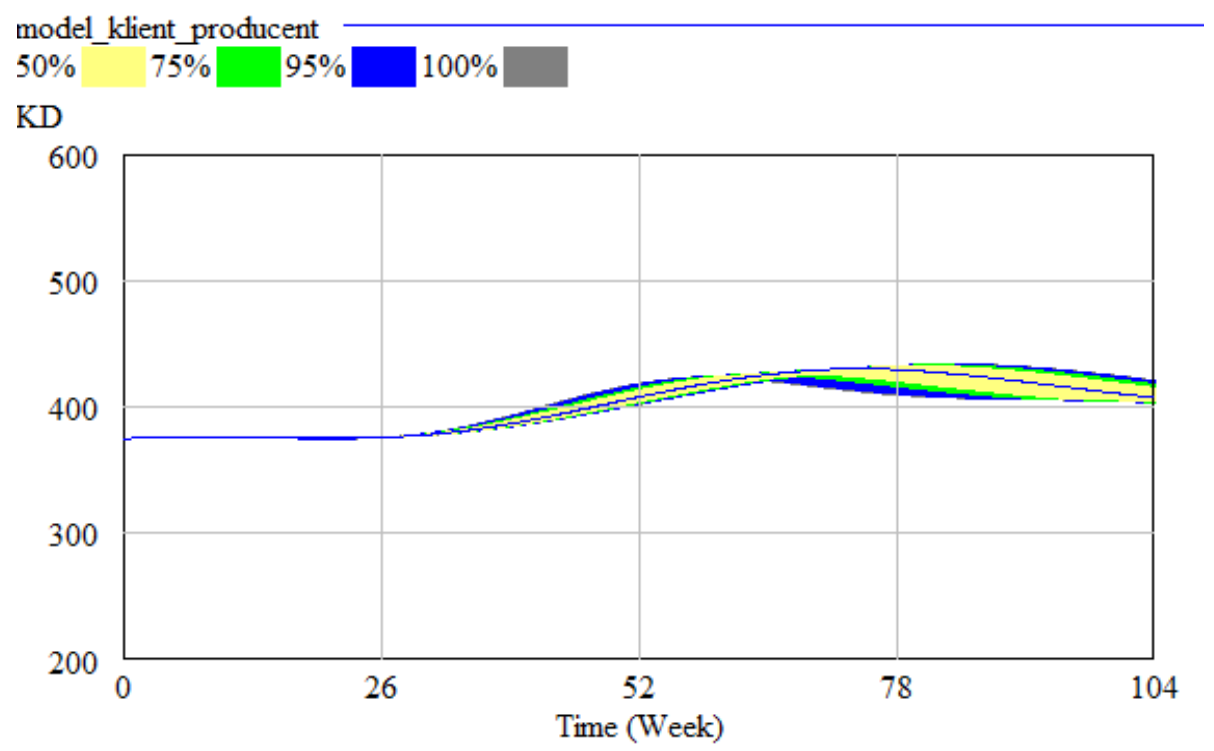

Figure 5. Confidence bounds for variable "KD", for variation of parameter "CLO" $\in(10,30)$

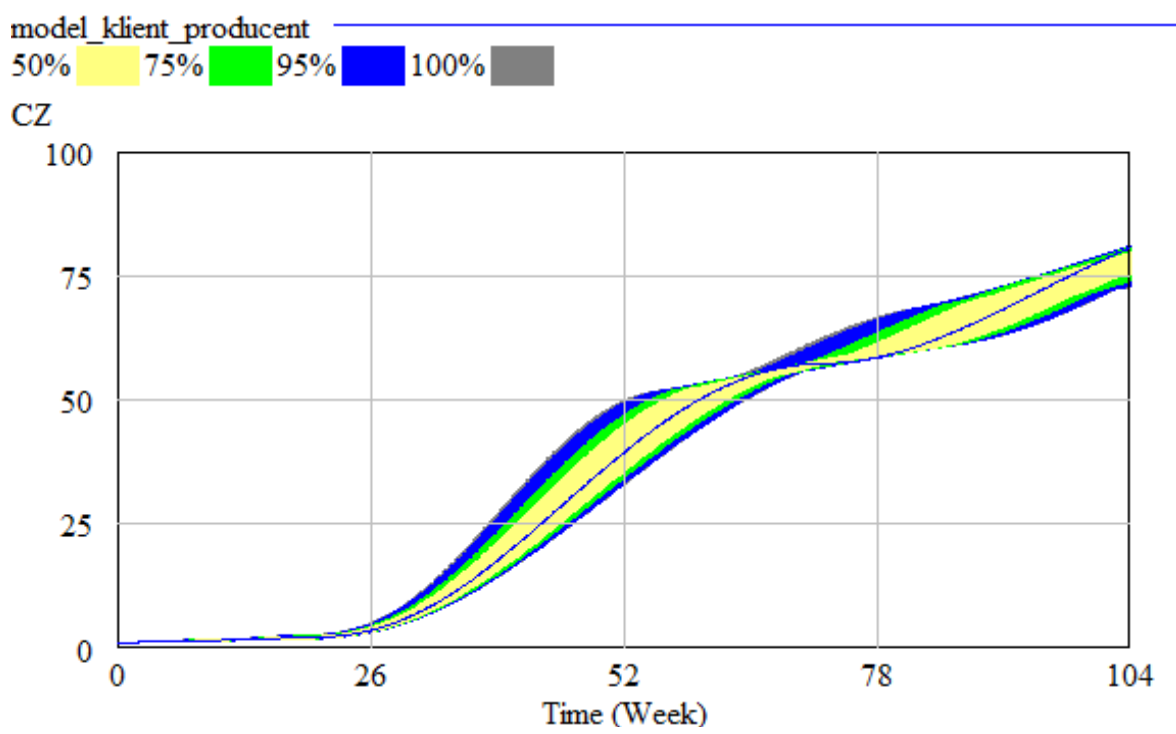

Figure 6. Confidence bounds for variable " $\mathrm{CZ}$ ", for variation of parameter "CLO" $\in(10,30)$ 
Our aim was to shorten the "CZ". As above we planned the optimization experiment, consisting in minimizing the value of that variable. The results of the experiment are presented in Table 2 .

The third problem is: Too large fluctuation of "KS" level (Cash Balance at Factory).

To conduct this experiment we selected the parameter "CWG1" (FinishedGoods Price at Factory), "SKW" (Standard Inventory Cost per Item at Factory), "WSP" (Wage Rate at Factory), "PRD" (Productivity of Labour at Factory). The observed confidence bounds for net profit are demonstrated in Figure 7.

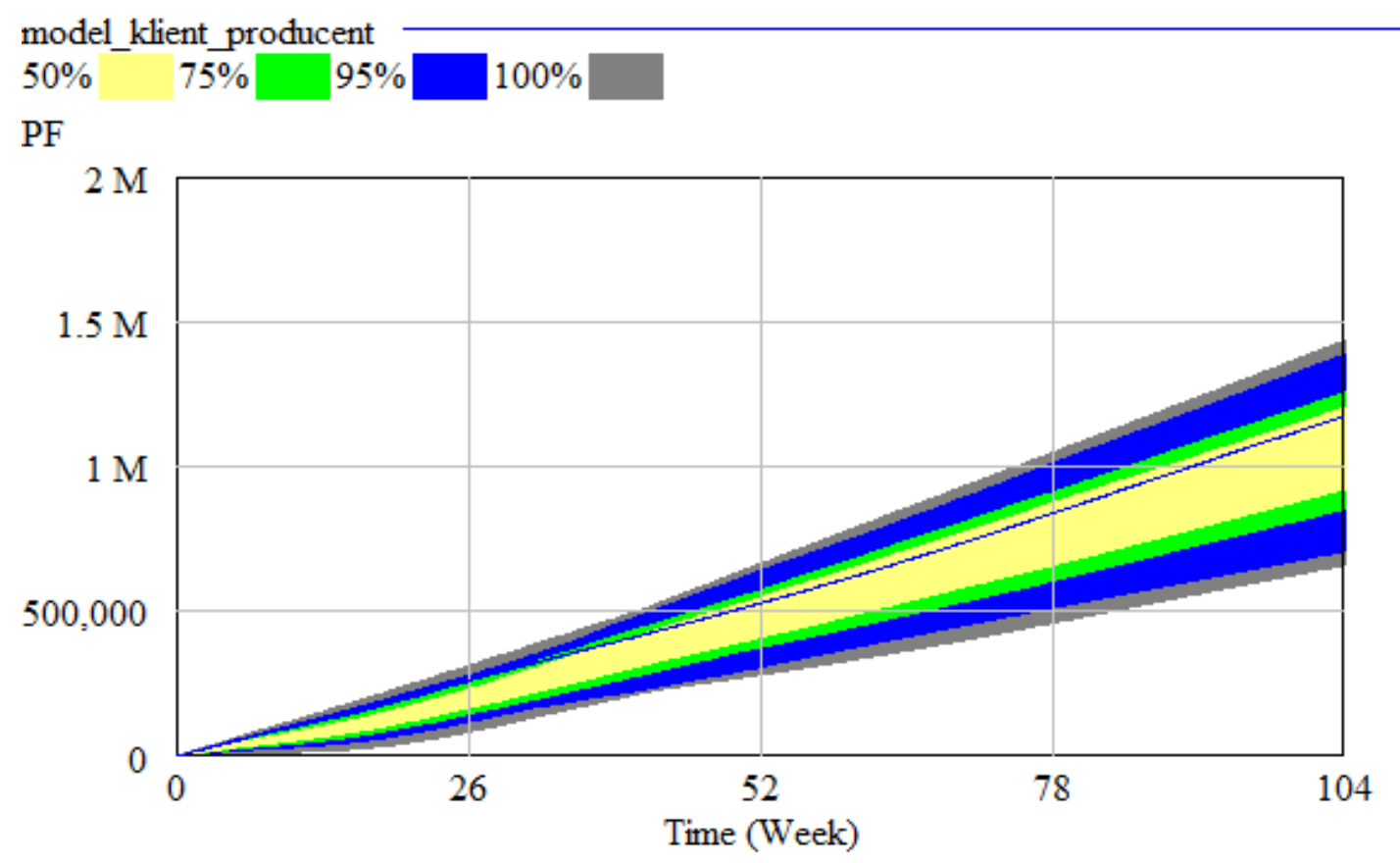

Figure 7. Confidence bounds for variable " $\mathrm{PF}$ ", for variation of parameters: "CWG1" $\epsilon(90,100)$, "SKW" $\epsilon(45,50)$, "WSP" $\epsilon(70,80)$, “PRD" $\epsilon(2,2.66)$

Our aim was to maximize "PF" (Net Profit Rate at Factory). We conducted the optimization by Vensim (see: windows in figures 8 and 9 ). The results are presented in Table 2. 


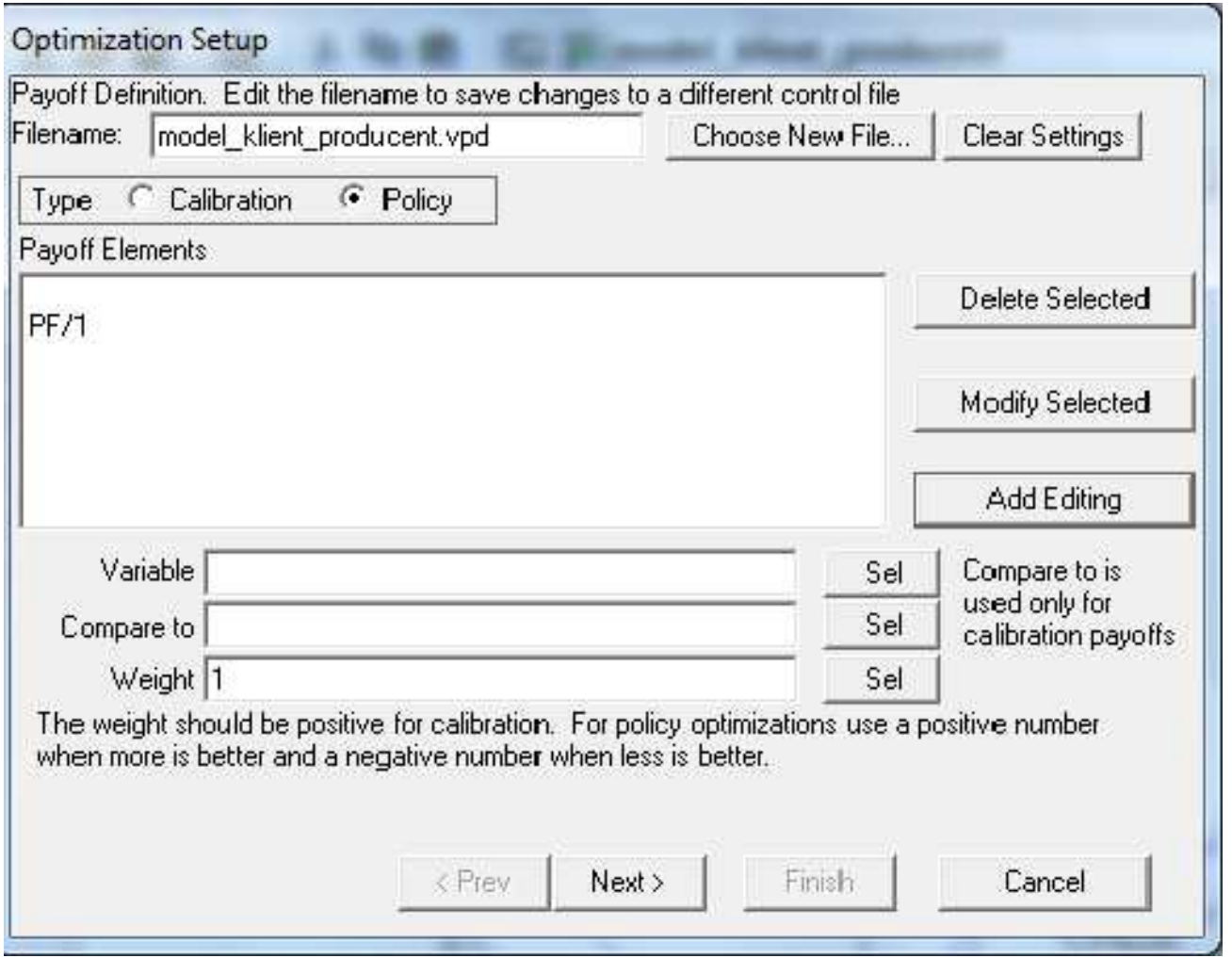

Figure 8. Optimization setup by Vensim

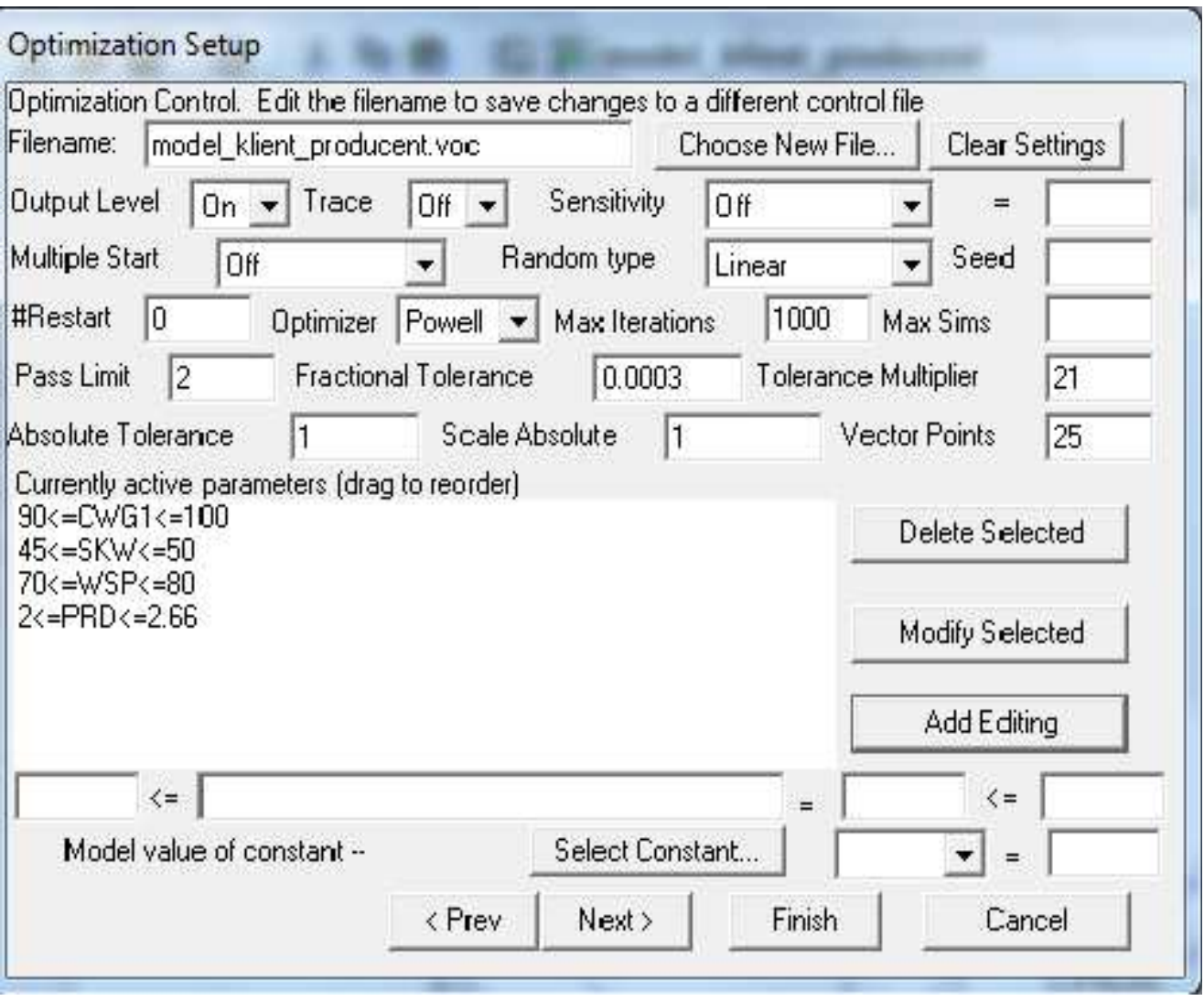

Figure 9. Optimization setup by Vensim 
Table 2. Results of optimization experiments for logistic problem

\begin{tabular}{|c|c|c|c|c|}
\hline $\begin{array}{l}\text { Problem } \\
\text { (no.) }\end{array}$ & $\begin{array}{c}\text { Type of } \\
\text { optimization } \\
\text { (MIN, MAX) }\end{array}$ & $\begin{array}{l}\text { Scope of } \\
\text { parameters }\end{array}$ & $\begin{array}{l}\text { Optimized values } \\
\text { of parameters }\end{array}$ & $\begin{array}{l}\text { Objective function } \\
\text { Initial value } \\
\text { Final value }\end{array}$ \\
\hline \multirow[t]{3}{*}{1.} & MIN & CUD $\in(3,5)$ & $C U D=3$ & $\begin{array}{c}C D=4.89912 \\
C D=4.2645\end{array}$ \\
\hline & & CZPM $\in(0.5,1)$ & $C Z P M=0.545774$ & \\
\hline & & CWG $\in(0.5,1)$ & $C W G=0.595165$ & \\
\hline 2. & MIN & CLO $\in(10,30)$ & $\mathrm{CLO}=30$ & $\begin{array}{l}C Z=3845.9 \\
C Z=3285.4\end{array}$ \\
\hline \multirow[t]{4}{*}{3.} & MAX & CWG1 $€(90,100)$ & CWG1 $=100$ & $\begin{array}{l}P F=1.286 e+006 \\
P F=1.417 e+006\end{array}$ \\
\hline & & SKW $\in(45,50)$ & $S K W=45$ & \\
\hline & & WSP $\in(70,80)$ & $W S P=80$ & \\
\hline & & $\mathrm{PRD} \in(2,2.66)$ & $\mathrm{PRD}=2$ & \\
\hline
\end{tabular}

The possibilities of such experimentations are practically unlimited, however, the scope of our paper does not allow to extend the analysis.

\section{Discussion of results}

The comparison of the initial and final values of objective functions in Table 2 allows us to ascertain that the choice of parameters and their scope was quite good, since the value of objective function has improved in all considered cases. The interesting fact is that the choice had "local" meaning (in the sense that parameters were from the sectors that were similar to objective functions).

Łukaszewicz (1975) ascertains that in large scale models there are few sensitive parameters and a lot of insensitive parameters. It is vital to detect those sensitive parameters and thus improve the behavior of the system. Naturally the 'trial-and-error' process is time and labor-consuming. This sensitive analysis by Vensim allows us to estimate the sensitiveness of selected variable for the choice of given parameters in an easier way and prepare the basis for optimization process.

It should be stressed that the obtained results are in line with specific assumption about the characteristics of the model entrance. Łukaszewicz in his paper (Łukaszewicz, 1975) recommended that the analysis of the model behavior should be under a wide spectrum of entrances, not only the classic "step" functions (like in our case) but the sinusoidal or linear ones (for example: trapezium). In books of Forrester (1961) and Łukaszewicz (1975) there are many examples of the analysis using the "trial and error" method. As a result of such analysis, the model behavior has been improved. In our paper we suggest the process of "automatic" sensitivity analysis and optimization by 
Vensim. Obviously, this simulation language was not known by Forrester or Łukaszewicz, and their results of simulation were time and labor-consuming, and impressive in their times.

\section{Conclusion}

Firstly, we would like to draw a number of theoretical conclusions:

- as Jackson (2006) said: "creative holism is necessary in the modern world. Managers are facing ever increasing complexity, change and diversity, and the solutions they have at their disposal to cope with these issue are inadequate". Thus we can say that the possibilities presented by SD are adequate for solving logistics problems in the firm.

- simulation - optimization experiments, on System Dynamics models allows to find sensitivity parameters and consequently conduct the search for optimal solution for multi-criteria problems (objective functions are modelled like inner elements of the model, with feedback in its structure),

- searching for optimal solutions can take into consideration different preferences of decision makers (different form of objective function, with possibilities of weighting parameters for their factors).

- Secondly, we would like to offer some practical conclusions:

- logistics problems in the firm can be investigated using sensitivity analysis and optimization by Vensim,

- the Vensim language should become popular in the environment of System Dynamics modellers, because it is an effective tool for such experiments as: simulation - optimization: its sensitivity and optimization setups allow almost automatic search for confidence bounds or optimal value of objective functions,

- doing simulation with complex, large scale models, requires seeking many versions of structures, many parameters (especially sensitive parameters), including random elements. All of this is offered by Vensim. Moreover, a new version of this language (see: Vensim 2013) allows its users to create interactive games. This constitutes a new direction of future investigations for the authors. 


\section{References}

Coyle, R.G. (1977). Management System Dynamics. Chichester: John Wiley \& Sons.

Coyle, R.G.(1994). Cosmic and Cosmoc. User Manuals. Londyn: The Cos-mic Holding Co.

Coyle, R.G. (1996). System Dynamics Modelling. A Practical Approach. Londyn: Chapman \& Hall.

Coyle, R.G. (1998). The practice system dynamics: Milestones, lessons and ideas from 30 years' experience. System Dynamics Review, 14 (4), 343-365.

Coyle, R.G. (1999). Simulation by repeated optimisation. Journal of the Operational Research Society, 50, 429-438.

Forrester, J. W. (1961). Industrial Dynamics. Cambrigde: MIT Press.

Forrester, J. W. (1969). Urban Dynamics. Cambrigde: MIT Press.

Forrester, J. W. (1971). World Dynamics. Waltham, MA: Pegasus Communications.

Forrester, J. W. (1972). Principles of Systems. Cambrigde: MIT Press.

Forrester, J. W. (1975). Collected Papers of Joy W. Forrester. Cambrigde: MIT Press.

Goncalves, G. (2009). World behaviour modes, pathways and overall trajectories, eigenvector and eigenvalue analysis of dynamic systems. System Dynamics Review, 25(1), 35-62.

Jacson, M. C. (2006). Creative holism: A critical systems approach to complex problem situations. System Research and Behavioural Science, 23, 647-657.

Kasperska, E. (1995). Symulacja komputerowa dla wspomagania podejmowanych decyzji gospodarczych w przedsiębiorstwie przemysłowym o produkcji ciągłej. Nowe kierunki badań. Organizacja i Kierowanie, 2, 65-70.

Kasperska, E. (1995). Badania symulacyjne na modelu SYMODREAL (model zakłóceń dostaw i produkcji zakładu przemysłowego). In: J. Bendkowski (Ed.), Zarzqdzanie przedsiębiorstwem przemysłowym. Problemy, metody, techniki. Gliwice: Wydawnictwo Politechniki Śląskiej.

Kasperska, E. (2002). Cybernetic Formulation of Some Functions of Management - Types of Simulation and Optimization Approaches within the System Dynamics Method. Proceedings of the 20th International Conference of the System Dynamics Society, Palermo, Italy. July 28 - August 1. P. I. Davidsen, E. Mollona, V. G. Diker, R. S. Langer, J. I. Rowe (Eds.).

Kasperska, E. (2003). System Dynamics Method and Supporting Decisions in Economic Organization. Proceedings of the 7th Conference of International Society for Decision Support Systems. DSS in the Uncertainty of the Internet Age. Katowice, Poland. July 13-16. T. Bui, H. Sroka, S. Stanek, J. Gołuchowski (Eds.). 
Kasperska, E. (2005). Some Remarks About Chosen Structural Aspect of System

Dynamics Method. 6 éme Congrées Européen de Science des Systémes,

AFSCET, Paris, France. September.

Kasperska, E. (2005). Modelling Embedded in Learning the Acceleration of

Learning by the Use of the Hybrid Models on the base of System Dynamics

Paradigm. In: T. Porębska-Miąc, H. Sroka (Ed.) Systemy Wspomagania

Organizacji. (pp. 410-417). Katowice: Wydawnictwo Uniwersytetu Ekonomicznego.

Kasperska,E.(2009). Metodologia budowyiwykorzystaniamodeliewolucyjnych $w$ aspekcie uczenia się $(w)$ organizacji społeczno-gospodarczej. Gliwice: Wydawnictwo Politechniki Śląskiej.

Kasperska, E., \& Mateja-Losa, E. (2005). Simulation Embedded in Optimization

- a Key for the Effective Learning Process in (about) Complex, Dynamical

Systems. Proc. of the 5th International Conference, Atlanta, USA. May.

(Eds.): V. S., Sunderman (et al.). Berlin: Springer.

Kasperska, E., \& Mateja-Losa, E. (2006). Extended Sensitivity Analysis of

Parameters and Structure in System Dynamics Models - Some Case Study.

Proc. of the 24th International Conference of the System Dynamics

Society, Nijmegen, The Netherlands. July. (Eds): A. Grossler (et al.). New

York: The System Dynamics Society.

Kasperska, E., Mateja-Losa, E., \& Słota, D. (2000). Some Extension of System

Dynamics Method - Theoretical Aspects. Proc. of the 16th IMACS World

Congress, Lausanne, Switzerland. August 21-25. M. Deville, R. Owens, (Eds.).

Kasperska, E., Mateja-Losa, E., \& Słota, D. (2001). Some Dynamics Balance of Production via Optimization and Simulation within System Dynamics Method. Proc. of the 19th International Conference of the System Dynamics Society, Atlanta, Georgia USA. July. J. H. Hines, V. G. Diker, R. S.Langer, J. I. Rowe, (Eds.), New York: The System Dynamics Society.

Kasperska, E., Mateja-Losa, E., \& Słota, D (2003). Optimal Dynamical Balance of Raw Materials - Some Concept of Embedding Optimization in Simulation on System Dynamics Models and Vice Versa. Proc. of the 20th International Conference of the System Dynamics Society, Palermo, Włochy. July 28 - August 1. P. I. Davidsen, E. Mollona, V. G. Diker, R. S. Langer, J. I. Rowe, (Eds.). New York: The System Dynamics Society. Kasperska, E., Mateja-Losa, E., \& Słota, D (2006). Comparison of Simulation and Optimization Possibilities for Languages: Dynamo and Cosmic and Cosmos - on a Base of the Chosen Model. Computational Science - ICCS 2006. 6 th International Conference reading, UK, May 28-31. Proceedings. Pt 1. V. N. Aleksandrov G. D. van Albada, P. M. A. Sloat, J. Dongarra (Eds.). LNCS 3991. Berlin: Springer.

Kasperska, E., Mateja-Losa, E., \& Słota, D (2006). Modelling and Simulation of the Organizational Changes Using System Dynamics Method - Some Case Study. Cybernetics and systems 2006. Proc. of the Eighteenth European 
Meeting on Cybernetics and Systems Research, Vienna, Austria. Robert Trapp (Eds.). Vienna: Austrian Society for Cybernetics Studies.

Kasperska, E., \& Słota, D. (2003). Two Different Methods of Embedding the Optimization in Simulation on Model Dynbalance (2-2). Proc. of the 21st International Conference of the System Dynamics Society, New York, USA. July. P. I. Davidsen, E. Mollona, V. G. Diker, R. S. Langer, J. I. Rowe, (Eds.). New York: The System Dynamics Society.

Kasperska, E., \& Słota, D. (2005). Modelling of the Evolution in the Structures, by the Use of Hybrid Models on the Base of System Dynamics. Proc. of the Conference of System Dynamics and Management Science: Sustainable development of Asia Pacific, Shanghai, China. November 4 to 6. (Eds.): Q. Wang (et al.).

Kasperska, E., \& Słota, D. (2005). Optimization Embedded in Simulation on Models Type System Dynamics - Some Case Study. Proc. of the 5 th International Conference, Atlanta, USA. May. (Eds.): V. S., Sunderman (et al.). Berlin: Springer.

Kasperska, E., \& Słota, D. (2006). Parallel Dual Problem of Optimization Embedded in Some Model Type System Dynamics. Proc. of the 24th International Conference of the System Dynamics Society, Nijmegen, The Netherlands. July 23-27. (Eds.): A. Grossler (et al.). New York: The System Dynamics Society.

Keloharju, R. (1977). System dynamics or super dynamics. Dynamica, 4, 26-43. Keloharju, R. (1980). General frame of resources structure and trade off. Dynamica, 6, 9-20.

Keloharju, R. (1983). Archiving structural sensitivity by automatic simplication. Dynamica, 9(2), 60-66.

Łukaszewicz, R. (1975). Dynamika systemów zarzqdzania. Warszawa: PWN.

Plate, R. (2010). Assessing individuals' understanding of nonlinear causal structures in complex systems. System Dynamics Review, 26 (1), 19-33.

Radosiński, E. (2001). Systemy informatyczne w dynamicznej analizie decyzji. Warszawa: PWN.

Sterman, J, D. (2000). Business Dynamics - System Thinking and Modelling for a Complex World. Boston: Mc Graw-Hill.

Sterman, J, D. (2002). All models are wrong: Reflections on becoming a system scientist. System Dynamics Review, 18(4), 501-531.

Wąsik, B. (1977). Modelowanie dynamiki systemów gospodarczych. Kraków: Wydawnictwo Akademii Ekonomicznej.

Wąsik, B. (1983). Elementy dynamiki systemowej dla ekonomistów. Kraków: Wydawnictwo Akademii Ekonomicznej.

Ventana Systems, Inc. (2007). Vensim User's Guide Version 5. Ventana Simulation Environment.

Ventana Systems, Inc. (2013). Vensim Version 6.1. Ventana Simulation Environment.

Winch, G. W. (1976). Optimization experiments with forecast bias. Dynamica, 2(3), 107-116. 


\section{Abstrakt (in Polish)}

Celem artykułu jest prezentacja wyników badań symulacyjnych i optymalizacyjnych przeprowadzonych przez autorów, a dotyczq̨cych wybranych problemów logistycznych występujq̨cych w firmach. Autorzy artykułu zastosowali metodę Dynamiki Systemowej (SD) i język symulacyjny Vensim w celu rozwiqzania określonych problemów opisanych w modelu Klient - Producent - Zatrudnienie autorstwa J. Forrestera. Historyczny już model Klient - Producent - Zatrudnienie Forrestera nigdy nie był badany w zakresie analizy wrażliwości - w sensie "automatycznej" analizy. Nie poddawano go również eksperymentom optymalizacyjnym. Jest to zaskakujqce, gdyż model ten jest stary i powszechnie znany. Możliwości języka symulacyjnego Vensim pozwalaja na przeprowadzenie takiej analizy. Autorzy wykorzystali wizualizację zwanq "confidence bounds" dla ukazania zachowania niektórych zmiennych występujqcych w modelu, w funkcji czasu. Język symulacyjny Vensim wykorzystuje metodę Monte-Carlo w próbkowaniu wybranych zmiennych występujqcych w modelu przy zadanym z góry zakresie zmienności (przy czym losowanie dokonywane jest zgodnie z rozkładem, który musi być znany). Autorzy pracy wykonali wiele eksperymentów w tym zakresie. Wyniki ich pracy sq zaprezentowane $w$ artykule. Na końcu sformułowano wnioski z przeprowadzonych badań.

Słowa kluczowe: Dynamika Systemowa, analiza wrażliwości, optymalizacja, Vensim. 